\title{
Uma análise da territorialização dos agrotóxicos na agricultura familiar de Guaranésia-MG
}

\author{
An analysis of the territorialization of pesticides in family farming in Guaranésia- MG
}

\author{
Renata Vieira de Melo \\ Mestre em Geografia - UNIFAL, Brasil \\ renata.vieirademelo78@gmail.com
}

\begin{abstract}
Resumo
No sul de Minas Gerais, mais precisamente na Região Geográfica Imediata de Guaxupé- MG, encontrase o município de Guaranésia-MG, onde a agricultura familiar está associada principalmente à produção de café e outras commodities, sendo esse município inserido na mundialização via cooperativas, e nesse sentido, a pressão econômica impõe aos agricultores familiares desafios para sua manutenção e reprodução de forma segura. Buscou-se compreender sobre as motivações na utilização de agrotóxicos, assim como, suas demandas de produção, a saúde destes produtores e de seus familiares, a disponibilidade de crédito agrícola para financiar a produção, suas percepções sobre o uso de agroquímicos, a rentabilidade agrícola e seus conhecimentos sobre produção orgânica. Para isso, utilizou-se a abordagem qualitativa como eixo fundamental e norteador das investigações, em complementaridade, utilizou-se a aplicação de questionário no trabalho de campo desenvolvido. Escolheu-se o contexto agropecuário de Guaranésia, por ser uma amostra da realidade sul mineira. Portanto, essa reflexão se justificou por buscar compreender a mundialização da agricultura, a territorialização do uso de agrotóxicos e consequentemente os impactos socioeconômicos para a agricultura familiar, e assim, poder elucidar a realidade agrária no município de Guaranésia-MG, como também no cenário nacional. Pode-se compreender a "força" e lobby do mercado e das cooperativas somados à atual inércia e retrocessos do Estado, nas esferas estadual e principalmente federal, nas políticas de valorização da agricultura familiar, compondo assim, obstáculos para a estruturação de uma política de alimentação saudável e segura para a população.
\end{abstract}

Palavras-chave: Agricultura Familiar; Agrotóxicos; Cafeicultura; Mundialização; Guaranésia-MG.

\begin{abstract}
In the south of Minas Gerais, more precisely in the Immediate Geographic Region of Guaxupé-MG, there is the municipality of Guaranésia-MG, where family farming is mainly associated with the production of coffee and other commodities. This municipality is inserted in the globalization via cooperatives. In this sense, the economic pressure imposes challenges on family farmers for their maintenance and safe reproduction. To understand the motivations in the use of pesticides, their production demands, the health of these producers and their families, the availability of agricultural credit to finance production, their perceptions about the use of agrochemicals, the agricultural profitability their knowledge of organic production. For this, the qualitative approach was used as a fundamental and guiding axis of the investigations. In complementarity, the questionnaire was used in the fieldwork developed. The agricultural context of Guaranésia was chosen, as it is a sample of the reality of southern Minas Gerais. Therefore, this reflection was justified by seeking to understand the globalization of agriculture, the territorialization of the use of pesticides and consequently the socioeconomic impacts for family farming, and thus, to be able to elucidate the agrarian reality in the municipality of Guaranésia-MG, as well as in the national scenario. It is possible to understand the "strength" and lobbying of the market and cooperatives, in addition to the current inertia and setbacks of the State, at the State and mainly federal levels, in the policies of valorization of family farming, thus composing obstacles to the structuring of a healthy and safe food policy for the population.
\end{abstract}

Keywords: Family farming; Pesticides; Coffee farming; Mundialization; Guaranésia-MG. 


\section{INTRODUÇÃO}

As recorrentes transformações no campo ocorreram a partir da chamada "Revolução Verde", a partir da década de 1960, a adoção de políticas neoliberais alterou significativamente os modos de produção com a inserção de novas práticas agrícolas justificadas na ampliação da produtividade do campo e proteção das plantas contra a ação das pragas.

Os agrotóxicos também intitulados de modo eufemístico de "defensivos agrícolas" se ampliaram sobre a argumentação de que estes garantiriam a produção de alimentos em larga escala para combater a fome e a proteção das plantações contra a ação de pragas.

A utilização maciça de agrotóxicos impactou a economia, apropriando o lucro agrícola dos pequenos agricultores, uma vez, que parte do capital é destinada a compra desse tipo de insumos revelando o intenso processo de subordinação da renda da terra ao capital industrial monopolista.

Nesta perspectiva, levando em consideração o uso crescente de agrotóxicos, a submissão dos agricultores ao uso destes produtos, a pressão exercida pelas cooperativas, essa reflexão se justifica por buscar compreender a territorialização dos agrotóxicos e consequentemente, os impactos socioeconômicos para a agricultura familiar, e assim, poder elucidar a realidade agrária não somente do município de estudo em questão como também regional.

O objetivo consiste em compreender a territorialização do agrotóxico na agricultura familiar do munícipio de Guaranésia-MG, com isso, ressaltar os impactos socioeconômicos e ambientais causados pelo uso abusivo destas substâncias nocivas a saúde dos agricultores familiares e consumidores de gêneros alimentícios.

Diante do exposto, nossa problemática é entender como ocorre a territorialização do o uso de agrotóxico na agricultura familiar no município, pois acreditamos que este represente um recorte espacial da realidade sul mineira, e a partir desta análise constatar se realmente apresenta uma viabilidade socioeconômica a utilização de agrotóxicos pelos agricultores familiares.

O presente artigo está estruturado em 5 partes apresentados da seguinte forma: inicialmente trataremos dos processos metodológicos que nortearam o desenvolvimento da pesquisa, em seguida, abordaremos como a territorialização e a monopolização se manifestam na agricultura brasileira. $\mathrm{Na}$ sequência discutiremos o papel da agricultura familiar, políticas e possibilidades, complementando com os dados e informações coletadas sobre o perfil dos agricultores e uso de agrotóxicos no local de estudo e região para então finalizar com as conclusões sobre a pesquisa.

\section{METODOLOGIA}

O estudo foi desenvolvido no município de Guaranésia situado no sul do estado de Minas Gerais estando inserido na Região Geográfica Imediata de Guaxupé- MG. Em sua extensão territorial 
de 294,828 km², além da sede municipal, temos um distrito, Santa Cruz da Prata, e mais oito comunidades composta por bairros rurais.

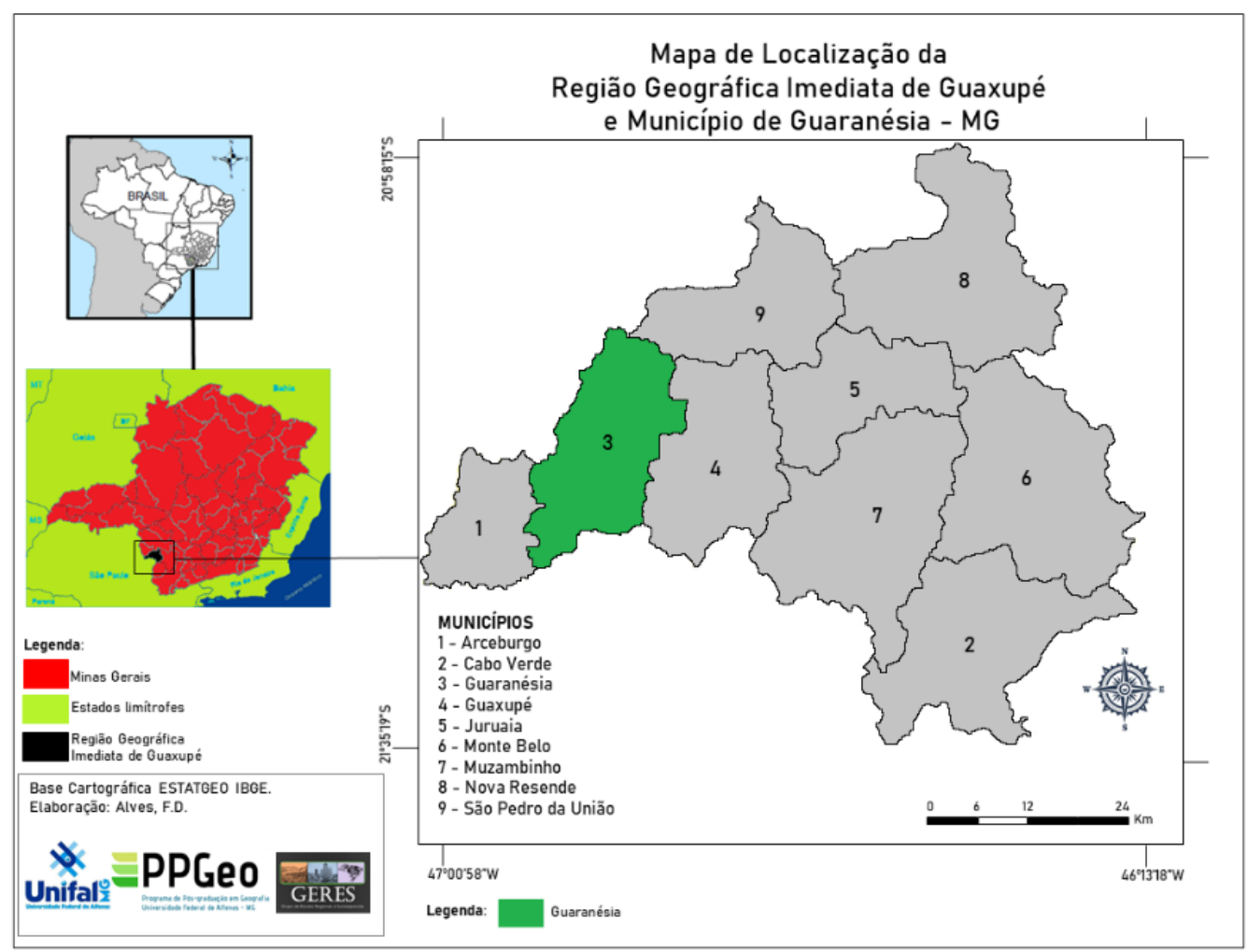

Figura 1 - Mapa de Localização da Região Geográfica Imediata de Guaxupé e Município de Guaranésia. Fonte: MELO; ALVES; (2020, p.228).

A escolha do município de Guaranésia-MG deve-se ao fato da presença da agricultura familiar e cafeicultura, e por acreditar que este seja uma amostra da realidade sul mineira, já que dispõe de uma organização social, política e econômica semelhante com os demais municípios que integram essa região.

O levantamento de dados secundários ocorreu por meio de consultas em diversos órgãos, entidades, institutos de pesquisas por meio do Instituto Brasileiro de Geografia e Estatística (IBGE / Produção Agrícola Municipal - PAM) / Sistema de Recuperação de Dados do IBGE - SIDRA); Empresa de Assistência Técnica e Extensão Rural do Estado de Minas Gerais (EMATER), Secretaria Municipal de Meio Ambiente e Agropecuária da Prefeitura Municipal, Cooperativa Regional de Cafeicultores em Guaxupé (COOXUPÉ), o Atlas: Geografia do Uso de Agrotóxicos no Brasil e Conexões com a União Europeia (BOMBARDI, 2017), dados junto ao SINAN - Ministério da Saúde e SINITOX - Fiocruz/Ministério da Saúde, respectivamente: Sistema Nacional de Agravo de Notificação e Sistema Nacional de Informações Tóxico - farmacológicas e também dados do DATASUS-Ministério da Saúde onde buscou-se notificações das intoxicações por agrotóxicos de uso agrícola no Estado de Minas Gerais, assim como, no município de estudo. 
Para obter os resultados e respostas acerca das nossas indagações, realizou-se a pesquisa utilizando da abordagem quali-quantitativa visando o levantamento de dados primários e informações por meio de entrevistas com questionário semiestruturado com agricultores familiares no município de Guaranésia - MG.

A partir do trabalho de campo realizamos registros fotográficos e mapeamos a espacialização destas propriedades no município de estudo.

\section{TERRITORIALIZAÇÃO DO CAPITAL E MONOPOLIZAÇÃO DO TERRITÓRIO PELO CAPITAL NA AGRICULTURA}

A prática da agricultura condiciona a transformação do território à modernização e mundialização da agricultura; por sua vez, alteram as bases do território sob a égide do capitalismo, portanto, o conceito de território e como a sua concepção nos leva diretamente a uma parte de compreensão essencial do nosso objeto de estudo que é a dinâmica da agricultura. Sendo de fundamental importância abordar os diversos rearranjos territoriais, ocasionados pelo desenvolvimento do sistema capitalista, assim como, o avanço do capitalismo sobre o campo e a cidade.

Para Raffestin (1993), o conceito de espaço está relacionado ao território, mas esse deve ser entendido como produto das relações socioculturais que se estabelecem no espaço, pois se forma a partir dele, sendo o produto de uma ação conduzida por um ator sintagmático em qualquer nível. Ao apropriar-se de um espaço, concreta ou abstratamente, o ator "territorializa-o".

Raffestin (1993) faz, ao definir território, conexões entre o território que é criado pelo poder de Estado (em suas várias esferas administrativas) e o transformado pelo poder de outros atores e agentes. Assim, o território mantém ativas e constantes relações de poder, que podem se refazer e dar origens a novos territórios, esse processo é contraditório e está associado aos interesses dos atores e agentes que produzem no espaço.

Em Oliveira (1999) há uma proposição em apreender o território como uma síntese contraditória do capitalismo em que sua configuração histórica se dá através das relações sociais de produção. Nesse cenário, o autor apresenta dois conceitos essenciais para nossa discussão: a territorialização do capital e a monopolização do território pelo capital.

A territorialização do capital se refere a um mecanismo especificamente capitalista, em que o capitalista se torna também proprietário de terra. Dessa forma, ocorre uma apropriação (pelo capitalista/proprietário) simultânea do lucro da atividade industrial e da agropecuária, como também da renda da terra, ou seja, o controle do território se dá nos processos produtivos como no processo de aquisição de terras. Como Oliveira $(2002$, p.106) aponta que a territorialização "varre do campo 
os trabalhadores, concentrando-os nas cidades [...] a reprodução ampliada do capital desenvolve-se em sua plenitude [...] a monocultura se implanta e define/caracteriza o campo".

Já a monopolização é uma maneira que o capital monopolista encontrou para se reproduzir através de formas não capitalistas de produção, redefinindo as relações de produção, na qual o próprio capital cria as condições para o campo produzir as matérias-primas para as indústrias capitalistas. Assim, Oliveira (2002, p.106) define a monopolização “o próprio capital cria as condições para que os camponeses produzam matérias-primas para as indústrias capitalistas ou mesmo viabilizem o consumo dos produtos industriais no campo"

De acordo com Oliveira (2000, p. 478-479) “o capital monopoliza o território sem, entretanto, territorializar-se, criando e se recriando, definindo e se redefinindo nas relações de trabalho e produção camponesa". Dessa forma, os agricultores e familiares inserem-se cada vez mais dentro da lógica do capital monopolista, perdendo sua autonomia e se sujeitando a renda da terra e do trabalho.

Sendo assim, com o processo de mundialização do capitalismo monopolista e consequentemente, do neoliberalismo, a agricultura capitalista também se transformou (OLIVEIRA, 2015). Portanto, faz-se necessário questionar o processo de territorialização e monopolização do capital na agricultura, por espelhar dinâmicas e dilemas da reprodução do capital.

É de fundamental importância realizarmos um breve resgate histórico para compreendermos as transformações sofridas pela agricultura brasileira, assim como, as consequências advindas do processo de modernização agrícola que desencadearam no atual contexto agrário.

A Revolução Verde, na qual a ideologia centrava na ampliação da produtividade, via sementes modificadas e combate às pragas por meios dos agroquímicos, é um marco histórico para todo esse processo de dominação capitalista no campo, pois ocorreram mudanças e alterações técnicas, produtivas, logísticas e socioculturais, que vão além do aumento significativo da produtividade, como também, há uma intencionalidade e um caráter político-ideológico no processo.

Como salientou Graziano da Silva (2003), o processo capitalista de desenvolvimento demonstrou seu caráter contraditório: crescimento da produção em contraste com o êxodo rural, longas jornadas de trabalho, concentração de propriedade e renda. Como também, não solucionou o problema da fome, aliás, fez com que ela aumentasse no mundo todo, geometricamente, devido aos impactos diretos causados no campo.

No entanto, o anseio pelo desenvolvimento econômico fez com que o Estado Nacional Brasileiro entrasse em atuação na adoção do pacote tecnológico, e por meio de políticas de concessão de créditos, possibilitou a importação de máquinas e agroquímicos.

Dentre as ações estatais destacamos a fundação de centros e instituições de pesquisa como a Empresa Brasileira de Pesquisas Agropecuária (EMBRAPA) em 1972, Empresa Brasileira de 
Assistência Técnica e Extensão Rural (EMBRATER) em 1974 e as Empresas de Assistência Técnica e Extensão Rural (EMATER) ligadas aos governos estaduais; o incentivo à formação de cooperativas voltadas a orientar, comercializar e agrupar produtores rurais e a designação de novas funções a serem exercidas pelo Banco do Brasil, a fim de fornecer créditos para financiar a compra dos pacotes tecnológicos.

Como o desempenho da agricultura depende de vários fatores surge a política de crédito agrícola. Nessa perspectiva surge o Sistema Nacional de Crédito Rural (SNCR), criado em 1964 pela lei 4.595, sendo esse o marco histórico da intervenção do governo na economia agrícola por meio de políticas públicas com o objetivo de modernizar e expandir a fronteira agrícola do país.

E em continuidade as ações do Estado em 1995, tem-se a criação do Programa Nacional de Fortalecimento da Agricultura Familiar (PRONAF) sendo ainda hoje um instrumento fundamental para o setor agrícola.

Com o apoio do Estado, o território brasileiro passa a ser um campo de atração das empresas multinacionais que ambicionavam expansão de seu capital. Um país de dimensões continentais de terras agricultáveis, com um mercado consumidor grande, com mão de obra farta, recursos naturais em abundância, somados a incentivos governamentais, transformaram o Brasil em alvo de investimento estrangeiro, e foi assim, que as empresas multinacionais se instalaram no território nacional, tornando a agricultura brasileira mundializada.

Coadunamos com o pensamento de Chesnais (1997):

Os fundamentos da mundialização atual são tanto políticos como econômicos. É apenas na vulgata neoliberal que o Estado é "exterior" ao "mercado". É preciso recusar as representações que gostariam que a mundialização fosse um desenvolvimento natural. $\mathrm{O}$ triunfo atual do "mercado" não poderia ser feito sem as intervenções políticas repetidas das instâncias políticas dos Estados capitalistas mais poderosos, os Estados Unidos assim os outros países membros do G7. (CHESNAIS, 1997, p.10).

Ao passo que as grandes corporações prosperam e as mudanças no direcionamento frente às novas exigências do mercado, faz com que, o Estado permita que o domínio seja das instituições que estão cada vez maiores e mais poderosas, participando ativamente de um jogo de interesses, que vai sendo entrelaçado por meio do controle e posse da terra, pela monopolização do território, pela territorialização do capital, por arrendamento, pelo silenciamento dos conflitos no campo, por programas sociais compensatórios, pelo consentimento do Estado.

A adoção do modelo político neoliberal pelos países da América Latina entre o final da década de 1980 e o início da década de 1990 concebeu uma mudança significativa no modo de produção agrícola, com claro incentivo à produção voltada para a exportação, sobretudo fundamentada em monoculturas latifundiárias. 
Sendo assim, a agricultura sob o viés capitalista neoliberal, voltada à acumulação massiva de lucro, pautou-se sobre três pilares para efetivar a reprodução do capital, são esses: a produção de commodities, as bolsas de mercadorias e de futuro e a formação de empresas monopolistas mundiais.

Os mecanismos utilizados pelo governo para a expansão da agricultura moderna possibilitaram a territorialização de grandes empresas agropecuárias de sementes, maquinários, agrotóxicos, dominando o espaço agrário brasileiro.

Portanto, a mundialização da agricultura contribuiu para que o Brasil se tornasse o maior consumidor de agrotóxicos do mundo e a insustentabilidade da agricultura capitalista por sua vez, tornou nossa agricultura dependente do setor monopolista agroquímico, onde o produtor depende da semente transgênica ou híbrida, que por sua vez depende de agrotóxicos ou fertilizantes para ser cultivada, destinando parte da sua renda para as empresas multinacionais deste setor, podendo levar ao seu próprio endividamento. E nesse processo de dependência são as grandes empresas mundiais que cada vez mais ditam as regras da produção agrícola mundial.

Em meio às consequências do processo de mundialização agrícola, valem ressaltar o elevado custo da implementação do pacote agroquímico no campo, em contrapartida o pequeno produtor familiar não possuía tal disponibilidade de capital, ficando, portanto, excluído de todo esse processo, ou ainda, tendo que encarar o endividamento para se inserir na nova lógica da agricultura, aumentando ainda mais as desigualdades no campo.

Em relação ao meio ambiente, esse processo foi um tanto quanto desastroso para a manutenção da diversidade ambiental, resultando em milhões de hectares de solos erodidos e pastagens degradados, cursos de água contaminados, desmatamento acelerado, dizimação de espécies vegetais e animais.

Com relação as vantagens econômicas, a formação de conglomerados são características inerentes à globalização, onde há a união e a formação de grandes estruturas organizacionais integradas em rede à economia global.

Sendo assim de acordo com Oliveira (2015),

Com o neoliberalismo assiste-se à formação de grupos ou conglomerados econômicos (economic groups ou economic conglomerates), entre essas empresas, que atuam articuladamente em termos mundiais, pelo processo de fusão, aquisição, associação etc., tornando-se esta sua característica principal.

(OLIVEIRA, 2015, p.241).

Portanto, é de fundamental importância dedicarmos uma atenção aos processos que circundam o mercado de agrotóxicos e como esses eles são integrantes de uma rede de estratégias mercadológicas vinculadas à agricultura globalizada. 
A expansão do agronegócio brasileiro levou o Brasil ao patamar de maior consumidor de agrotóxicos no mundo, o modelo de agricultura adotado pelo país requer grandes demandas de agrotóxicos, a esse modelo, nos referimos à monocultura de cana de açúcar, café, soja, milho.

Nesse contexto:

O histórico da instalação do paradigma da intensa utilização de venenos agrícolas no Brasil e consequentemente da implantação do monopólio das indústrias de agrotóxicos no cenário nacional representa, com clareza vários aspectos da transformação da agricultura capitalista, que implantou um império monopolista da indústria de alimentos, cujo intuito não é saciar a fome, mas abastecer a ganância econômica da modernidade, qual seja, o domínio e controle universal dos alimentos e insumos químicos que se tornaram imprescindíveis para o campo moderno. (SAMPAIO; GONÇALVES NETO, 2018, p. 123).

\section{AGRICULTURA FAMILIAR E DESENVOLVIMENTO RURAL: CARACTERÍSTICAS, DESAFIOS E POSSIBILIDADES}

A agricultura familiar tem uma importância valiosa e majoritária na produção de alimentos para o país e compõe a maior parte numérica de localidades agropecuárias brasileiras. De acordo com os dados do último Censo Agropecuário do IBGE realizado em 2017, o Brasil possui 5.073.324 estabelecimentos agropecuários, e desse total 3.897.408 são considerados estabelecimentos onde se pratica a agricultura familiar, ou seja $77 \%$ do total ocupando uma área equivalente a 81 milhões de hectares.

Em contrapartida, o agronegócio tem se dedicado a produção de commodities de exportação aliado ao capital financeiro, industrial e ao grande latifúndio, o que demonstra que não está em seus interesses abastecer o mercado interno. Nesse sentido, a agricultura familiar torna-se objeto de estudo da questão agrária no tocante de políticas públicas voltadas para o desenvolvimento desse segmento fundamental para a sociedade no que tange sua importância socioeconômica no cenário nacional.

A partir da década de 1990, com a criação do PRONAF, a agricultura familiar ganhou importância em termos econômicos e tecnológicos, dentro do contexto da financeirização da agricultura sobre isso:

O surgimento e o reconhecimento da agricultura familiar no Brasil é muito recente e deve-se à três fatores igualmente importantes. $\mathrm{O}$ primeiro tem a ver com a retomada do papel do movimento sindical após o fim da ditatura militar; o segundo está relacionado ao papel dos mediadores e intelectuais, especialmente cientistas sociais que debateram o tema no início da década de 1990; e o terceiro fator está relacionado ao papel do Estado e das políticas públicas, que passaram a reconhecer este setor e dar-lhe visibilidade a partir da criação do Programa Nacional de Fortalecimento da Agricultura Familiar (PRONAF). (SCHNEIDER; CASSOL, 2013, p.5).

Picolotto (2014) considera que três conjuntos de atores foram fundamentais no processo de construção da categoria da agricultura familiar no Brasil sendo esses: os estudos e pesquisas acadêmicas, as políticas de Estados e as normativas legais e a organização de agricultores familiares. 
No que tange a políticas públicas, Picolotto (2014) identifica uma maior representatividade política da agricultura familiar com a Lei da Agricultura Familiar (11.326/06), assim como, outras políticas criadas em favorecimento a essa categoria.

A novidade do PRONAF “estava em sua intenção explícita de propiciar aumento da geração de renda dos agricultores por meio de seu acesso ao crédito bancário" (ABRAMOVAY; PIKETTI, 2005, p.58).

O PRONAF é estruturado em linhas de créditos especificadas e os indivíduos que as solicitam são enquadrados de acordo com os critérios de cada linha, respeitando a obrigatoriedade da participação na agricultura familiar.

Ao passo que o PRONAF foi estabelecendo novas linhas de crédito surgiram discussões acerca das características socioeconômicas dos agricultores familiares, e tais particularidades eram primordiais para definir se esse produtor fazia parte ou não dos contemplados pelo programa.

Efetivamente, afim de conceituações mais assertivas a agricultura familiar consiste em uma unidade de produção onde haja membros de uma família trabalhando em atividades diversas que não seja somente a produção, mas também a administração da propriedade, portanto:

\begin{abstract}
A agricultura familiar é aquela em que a gestão, a propriedade e a maior parte do trabalho, vêm de indivíduos que mantêm entre si laços de sangue ou de casamento. Que esta definição não seja unânime e muitas vezes tampouco operacional. É perfeitamente compreensível, já que os diferentes setores sociais e suas representações constroem categorias científicas que servirão a certas finalidades práticas: a definição de agricultura familiar, para fins de atribuição de crédito, pode não ser exatamente a mesma daquela estabelecida com finalidades de quantificação estatística num estudo acadêmico. $\mathrm{O}$ importante é que estes três atributos básicos (gestão, propriedade e trabalho familiar) estão presentes em todas elas. (ABRAMOVAY, 1997, p.3).
\end{abstract}

Posto isso, a Lei $\mathrm{n}^{\mathrm{o}} 11.326$, de 24 de julho de 2006 considera-se agricultor familiar e empreendedor familiar rural aquele que pratica atividades no meio rural, atendendo, simultaneamente, aos seguintes requisitos:

Art. $3^{\circ}$ :

I - Não detenha, a qualquer título, área maior do que 4 (quatro) módulos fiscais;

II - Utilize predominantemente mão-de-obra da própria família nas atividades econômicas do seu estabelecimento ou empreendimento;

III - tenha percentual mínimo da renda familiar originada de atividades econômicas do seu estabelecimento ou empreendimento, na forma definida pelo Poder Executivo;

IV - Dirija seu estabelecimento ou empreendimento com sua família. (BRASIL, 2006).

Em contrapartida podemos verificar a importância de outros programas governamentais que contemplam a produção familiar fora dos preceitos do agronegócio como o Programa Nacional de Alimentação Escolar (PNAE), programa destinado ao fornecimento de alimentos às escolas do município, assim como abastecem a feira livre da agricultura familiar, suas principais produções contam com legumes, verduras e frutas. O Programa de Aquisição de Alimentos (PAA) está ligado 
ao Ministério do Desenvolvimento Social, criado pelo art. 19 da Lei $n^{\circ} 10.696$, de 02 de julho de 2003, tem como finalidades básicas promover o acesso à alimentação e incentivar a agricultura familiar (BRASIL, 2003).

Esses programas atuaram como instrumentos de intervenção do Estado no processo de produção e comercialização dos produtos provenientes da agricultura familiar. A partir deles ocorre a geração de renda, assim como, diminuindo as desigualdades no campo, protegendo a produção familiar e a permanência no campo.

A feira livre da agricultura familiar é uma alternativa econômica para os agricultores familiares residentes no município de Guaranésia-MG. Os produtos são plantados em sítios e chácaras próprios ou arrendados localizados na área rural, distrito e bairros rurais do município.

É de fundamental importância promover a disseminação de hábitos alimentares saudáveis e no tocante a realidade municipal o desenvolvimento de modos de produção mais equilibrados ecologicamente, viáveis economicamente e justos socialmente podem ser fomentados pela feira através da produção orgânica, e futuramente estendida a uma produção agroecológica.

Mesmo que a Produção Orgânica de alimentos não tenha como premissa única a produção no contexto da Agricultura Familiar, esse espaço se constitui como o lócus ideal para o desenvolvimento da Agroecologia, tendo em vista que é nesse espaço que suas bases (sociais, econômicas, ambientais, culturais) podem ser desenvolvidas, respeitadas e fortalecidas (IBAMA, 2019).

A Agroecologia sugere que a relação entre o homem e o meio aconteça de modo mais sustentável incorporando o funcionamento ecológico necessário a fim de eliminar as práticas predadoras comuns na agricultura capitalista. Sendo assim, a Agroecologia contribui para desmontar os modelos agroquímicos tradicionais por meio da inserção de suas técnicas e suas práticas em uma nova teoria da produção (LEFF, 1994, 2000).

Segundo Altieri (1995), a Agroecologia constitui um enfoque teórico e metodológico que, lançando mão de diversas disciplinas científicas, pretende estudar a atividade agrária sob uma perspectiva ecológica. Entretanto, é preciso considerar que:

A Agroecologia não se propõe como uma panaceia para resolver todos os problemas gerados pelas ações antrópicas de nossos modelos de produção e de consumo, nem espera ser a solução para as mazelas causadas pelas estruturas econômicas globalizadas e oligopolizadas, senão que busca, simplesmente, orientar estratégias de desenvolvimento rural mais sustentáveis e de transição para estilos de agriculturas mais sustentáveis, como uma contribuição para a vida das atuais e das futuras gerações neste planeta de recursos limitados (CAPORAL, 2009, p.13).

São justamente os pequenos agricultores que estão mais aptos à conversão para sistemas de produção agrícola baseados em princípios agroecológicos. Diante disso, é necessário ampara-los com políticas públicas que estimulem a produção de alimentos saudáveis sem agrotóxicos, para enfim, 
pode trazer resultados socioambientais sem precedentes para a população, a começar pela inclusão de agricultores marginalizados no atual modelo produtivo inserindo-os no processo de produção livre dessas substâncias (PORTO; SOARES, 2012).

Dentre as várias abordagens teóricas concebidas pelos autores Schneider (2010) afirma que de modo geral os estudiosos parecem concordar que:

Primeiro, os estudiosos parecem concordar que a usual redução do espaço rural às atividades agropecuárias perdeu sentido na atualidade, colocando-se o desafio de pensar as interfaces e os atributos que caracterizam o espaço e seu conteúdo como um todo. Segundo, há um relativo consenso sobre a dimensão multidimensional da sustentabilidade do desenvolvimento, assim como em relação ao papel da agricultura familiar e das formas heterogêneas de sua inserção na dinâmica da economia capitalista. Terceiro, mesmo que de forma difusa, as abordagens parecem concordar que no Brasil o foco das ações do desenvolvimento rural deve ser o combate à pobreza e às múltiplas vulnerabilidades das populações rurais. (SCHNEIDER, 2010, p.528).

Coadunando com Veiga (1994), Abramovay (1996) acredita que a politização da agricultura familiar seja fundamental para abarcar políticas públicas voltadas as urgências do setor rurais sendo essas educacionais, creditícias, tecnológicas, estruturais, técnicas.

Uma vez que o campo seja remodelado a partir de uma redistribuição de terras e melhorias nos setores profissionais, educacionais, financeiros, técnicos haveria o surgimento de um novo campo, estruturado sob moldes diferentes do atual modelo agrário.

O que se propõe é que a partir da junção entre políticas públicas eficientes, reforma agrária e valorizações da agricultura familiar possam iniciar um processo gradual onde ocorra uma transição nos modos de produção, nas relações estabelecidas entre campo e cidade, na capacitação do trabalhador, na geração de empregos no campo, no respeito ao meio ambiente.

As bases dessas mudanças seriam através da produção de alimentos saudáveis, sem veneno, comercializadas a preço justo em escala local, regional e nacional para alimentar nossa população, culminando na soberania alimentar, na geração de empregos na agricultura minimizando os efeitos da migração campo-cidade.

\section{POLÍTICAS E USOS DO AGROTÓXICO NO BRASIL}

Agrotóxicos, defensivos agrícolas, pesticidas, veneno são algumas terminologias comumente utilizadas para denominar as substâncias químicas produzidas para eliminar ervas daninhas e doenças que acometem as plantações.

Em outros países, devido a variação linguística observamos que:

$\mathrm{Na}$ literatura internacional em língua inglesa, o grupo de substâncias/ produtos químicos aqui definido como agrotóxico recebe a denominação de pesticida (pesticide). $\mathrm{O}$ termo "agroquímico" - o mais próximo de agrotóxico encontrado em literatura de língua inglesa (agrochemicals) e, em menor escala, também na língua portuguesa - engloba um número 
maior de produtos, como os fertilizantes e adubos inorgânicos. Portanto, não representa o real sentido do termo agrotóxico, que indica não apenas a sua finalidade de uso, mas também o caráter prejudicial destas substâncias, visualizado no radical "tóxico". (PERES, 2001, p.23).

O uso do termo agrotóxico de acordo com o manual da OPAS/OMS (1996), substituiu a designação —-defensivo agrícola após grande manifestação da sociedade civil organizada com o propósito de evidenciar a toxicidade destes produtos para a saúde humana e o meio ambiente.

A Agencia Nacional da Vigilância Sanitária (ANVISA) é responsável pela avaliação toxicologia, assim como, avaliação dos riscos para saúde humana.

A legislação brasileira apresenta ambiguidades, distorções e fragilidades, no que se refere à regulamentação dos processos de registro de permanência dos agrotóxicos e dos indicadores de classificação toxicológica (GARCIA et al., 2005; FARIA et al., 2007; PELAEZ et al., 2013). A grande problemática em relação a legislação brasileira está na condição de registro, assim como, na permanência praticamente vitalícia do mesmo, uma vez que, o registro de agrotóxicos no Brasil não possui previsão legal para renovação ou revalidação. Portanto, uma vez concedido, o registro de agrotóxicos possui validade indeterminada.

Conforme já constatado por Bombardi (2017), “de toda forma, continua sendo a Legislação um balizador para a utilização de agroquímicos, mediando, ao menos hipoteticamente, a salvaguarda humana ambiental".

A Lei 7.802, de 1989, e o Decreto 4.074, de 04 de janeiro de 2002, definem as características proibitivas de registro de agrotóxicos no Brasil e determinam que os ingredientes ativos de agrotóxicos poderão ter seus registros cancelados quando se enquadrarem nas seguintes condições relacionadas à saúde humana:

Quando não possuírem antídoto ou tratamento eficaz no Brasil; se forem considerados teratogênicos, carcinogênicos ou mutagênicos; se provocarem distúrbios hormonais e danos ao aparelho reprodutor ou se forem mais perigosos para o homem do que demonstrado em testes com animais de laboratório. (BRASIL, 2002).

Diante disso:

Se a legislação Brasileira no tocante ao uso de agrotóxico permite, ao mesmo tempo, que o registro de um ingrediente ativo (agrotóxico) se dê por tempo indeterminado e que a reavaliação de um determinado ingrediente ativo se dê apenas em casos extremos (efeitos carcinogênicos, mutagênicos e teratogênicos) podemos observar um princípio bastante diferente deste existente na Legislação da União Europeia. (BOMBARDI, 2017, p.41).

A reavaliação toxicológica dos efeitos de um ingrediente ativo de agrotóxico na saúde humana exige a análise minuciosa e detalhada de uma série de estudos toxicológicos a ANVISA acompanha a implementação das medidas regulatórias estabelecidas após a reavaliação. O exemplo 
disso, podemos citar alguns agrotóxicos que já foram submetidos à reavaliação segue a tabela 1 abaixo:

Tabela 1: Reavaliação de ingredientes ativos de agrotóxicos.

\begin{tabular}{cccc}
\hline Ingrediente Ativo & Inicio & Final & Situação atual \\
\hline $2,4-\mathrm{D}$ & RDC 124/2006 & RDC 284/2019 & Mantido com restrições no registro \\
Acefato & RDC 10/2008 & RDC 45/2013 & Mantido com restrições no registro \\
Cihexatina & RDC 10/2008 & RDC 34/2009 & Proibido \\
Carbofurano & RDC 10/2008 & RDC 185/2017 & Proibido \\
Endossulfam & RDC 10/2008 & RDC 28/2010 & Proibido \\
\hline
\end{tabular}

Fonte: ANVISA, 2020.

Recentemente, mais precisamente em setembro de 2020, o Paraquat (Paraquate) foi proibido no Brasil depois de seguir todos os procedimentos citados anteriormente, e também, há outros ingredientes ativos que aguardam a avaliação como, por exemplo, o Glifosato.

Diferente de países que fazem reavaliações periódicas de agrotóxicos e ingredientes ativos, no Brasil o processo além de burocrático é lento e muito exigente para retirada e/ou proibição de ingredientes químicos letais (agrotóxicos) ao passo que é permissivo ao registro dos mesmos. Como comprovação observamos um caminho para retirada de agrotóxicos do mercado, como no caso do Glifosato que está em análise inconclusivas, enquanto o registro de novos agrotóxicos segue avançando recordes históricos sendo mais de 700 aprovações de novos registros entre janeiro de 2019 a setembro de 2020. Neste aspecto, Garcia (2005) evidencia que a não realização de avaliações periódicas possibilita a existência e utilização de produtos que não deveriam permanecer no mercado, quiçá utilizados e consumidos pela população.

O que evidenciamos é que além de permitir o uso de produtos banidos em outros países, as leis são constantemente pressionadas a flexibilizar as medidas protetivas pelas corporações associadas ao agronegócio (ABRASCO, 2012).

Para a fiscalização existe o Programa de Análise de Resíduos de Agrotóxicos em Alimentos (PARA) foi criado em 2001 com o objetivo de avaliar, os níveis de resíduos de agrotóxicos nos alimentos de origem vegetal que chegam à mesa do consumidor. Em todos esses processos existe o Limite Máximo de Resíduo (LMR) é a quantidade máxima de resíduos de agrotóxicos ou afins oficialmente permitida no alimento - em decorrência da aplicação em uma cultura agrícola, expresso em miligramas do agrotóxico por quilo do alimento $(\mathrm{mg} / \mathrm{Kg})$. Entretanto, o risco aceitável se torna questionável ao não considerar diferentes grupos geracionais mais vulneráveis como crianças, idosos, gestantes, o que expõe essas populações a riscos letais através das noções de uso seguro ou de uso 
racional dos agrotóxicos quando na verdade temos 34.147 intoxicações registradas pelo Ministério da saúde entre os anos de 2007 a 2014 (MINISTÉRIO DA SAÚDE, 2015).

No entanto, BOMBARDI (2017) ao comparar a realidade brasileira com a europeia identifica:

Tabela 2: Comparação do limite máximo de resíduos (LMR) dos alimentos no Brasil e na União Europeia.

\begin{tabular}{ccccc}
\hline Produto & Ingrediente Ativo & LMR-UE & LMR-Brasil & Comparação \\
\hline Arroz & $2,4-\mathrm{D}$ & $0,1 \mathrm{mg} / \mathrm{kg}$ & $0,2 \mathrm{mg} / \mathrm{kg}$ & 2 vezes maior \\
Milho & Atrazina & $0,05 \mathrm{mg} / \mathrm{kg}$ & $0,025 \mathrm{mg} / \mathrm{kg}$ & 5 vezes maior \\
Sorgo & Atrazina & $0,05 \mathrm{mg} / \mathrm{kg}$ & $0,025 \mathrm{mg} / \mathrm{kg}$ & $5 \mathrm{vezes} \mathrm{maior}$ \\
Feijão & Malationa & $0,02 \mathrm{mg} / \mathrm{kg}$ & $8 \mathrm{mg} / \mathrm{kg}$ & 400 vezes maior \\
Café & Glifosato & $0,1 \mathrm{mg} / \mathrm{kg}$ & $1 \mathrm{mg} / \mathrm{kg}$ & 10 vezes maior \\
Cana de açúcar & Glifosato & $0,05 \mathrm{mg} / \mathrm{kg}$ & $1 \mathrm{mg} / \mathrm{kg}$ & 20 vezes maior \\
Soja & Glifosato & $0,05 \mathrm{mg} / \mathrm{kg}$ & $10 \mathrm{mg} / \mathrm{kg}$ & 200 vezes maior \\
\hline
\end{tabular}

Fonte: adaptado de BOMBARDI (2017).

Para cada ingrediente ativo existe um LMR que pode variar, destacamos quatro ingredientes ativos o 2,4-D, Atrazina, Malationa e Glifosato que são herbicidas e inseticidas perigosos ao meio ambiente, potencialmente carcinogênicos e associados a diversos males a saúde humana e que são usados aqui em quantidades potencialmente superiores que demais países do mundo.

No tocante aos benefícios concedidos ao agronegócio brasileiro está a isenção fiscal dos agrotóxicos, e também, redução de impostos, tarifas, subsídios proporcionados, empréstimos, e até mesmo a anistia para grandes produtores.

O consumo de agrotóxicos relaciona-se diretamente com a adoção do modelo de agricultura intitulado 'agronegócio', que é uma relação comercial e industrial atrelada ao mercado internacional e também a produção de commodities de exportação.

Em razão da insustentabilidade do sistema jurídico brasileiro acima identificada, percebe-se que "há uma privatização dos lucros e uma socialização dos riscos, bastando para tanto registrar que quem arca com o tratamento das doenças ocasionadas pelos pesticidas é a própria sociedade" (FERREIRA, 2015. p. 33).

É possível visualizar a concentração do poder do império do agrotóxico pelo número pequeno de empresas que controlam a maior parte do mercado de agrotóxicos no Brasil. Em 2017, as dez maiores responderam por cerca de $80 \%$ do total comercializado no Brasil, enquanto as quinze maiores responderam por cerca de 96\%. Além disso, a concentração se tornou maior em razão do processo de fusões e aquisições no setor ocorrido em período recente, facilitando a mobilização. 
Dessa forma, Ploeg (2008) concluiu que a agricultura não estaria mais voltada para alimentar a população mundial de forma saudável e sustentável, mas voltada ao objetivo de lucrar em detrimento da saúde humana.

Nesse aspecto, na análise de Palaez (2015):

Em um contexto histórico de crescente oneração fiscal do Estado sobre a economia, a agenda política relativa à produção de agrotóxicos no país mantém o foco no estímulo ao seu consumo, via a redução de impostos e a agilização do processo de aprovação dos pleitos de registro. Ao mesmo tempo, são negligenciadas as possibilidades de ampliação de recursos para a regulação social desses produtos (PELAEZ, 2015, p.170).

Segundo a Organização Mundial da Saúde (OMS) são registradas 20 mil mortes por ano devido o consumo de agrotóxicos. O Brasil vem sendo o país com maior consumo destes produtos desde 2008, decorrente do desenvolvimento do agronegócio no setor econômico, havendo sérios problemas quanto ao uso de agrotóxicos no país: permissão de agrotóxicos já banidos em outros países e venda ilegal de agrotóxico que já foram proibidos. A exposição aos agrotóxicos pode causar uma série de doenças, dependendo do produto que foi utilizado, do tempo de exposição e quantidade de produto absorvido pelo organismo (INCA,2019).

O uso de agrotóxicos pode diminuir as perdas ocasionadas pelas pragas daninhas, doenças e ataques de insetos, mas a utilização destes geram riscos à saúde para quem transporta, aplica ou consome produtos que são tratados com essas substâncias. Danos como intoxicações agudas e crônicas, onde muitas vezes provoca consequências irreversíveis ou até o óbito do trabalhador. As vias de exposições mais comuns são ocular, respiratória, dérmica e oral (ANDEF, 2006; VEIGA, 2007).

Neste processo agroquímico dependente, os fazendeiros contaminam a lavoura, o produto, o ambiente, os trabalhadores rurais e a população do entorno com o objetivo de atingir o alvo ou as "pragas" da lavoura (inseto, fungo ou erva daninha), tratam-se de poluições intencionais e não “derivas" que culpa o clima ou o pulverizador (CARNEIRO et al., 2012; AUGUSTO et al., 2012; RIGOTTO et al., 2012).

De acordo com o SINITOX em 2017 na região sudeste do Brasil foram notificados 1.373 casos de intoxicação por agrotóxicos, sendo 1.119 por agrotóxicos de uso agrícola e 184 por agrotóxicos de uso domésticos. Levando em consideração que as subnotificações são uma realidade, estimasse que a cada 1 notificação 50 não sejam notificados, assim resulta-se em 68.650 intoxicações no ano de 2017 na região sudeste (MINISTÉRIO DA SAÚDE/SINITOX, 2018).

Em contrapartida, Soares e Porto (2007) estimam que, anualmente, 540 mil trabalhadores rurais brasileiros são contaminados por agrotóxicos no país, sendo que destes casos 4 mil resultam em morte. 
Lobato (2003) afirma que este caráter de banalização dos sintomas relatados pelos trabalhadores expostos a agrotóxicos é uma tentativa de se proteger da tragédia parcialmente percebida, assim, ocorre uma minimização dos impactos e negligencias com a saúde pública.

Observa-se a fragilidade da agricultura familiar em relação ao uso de agrotóxicos. A exposição a essas substâncias tende a ser mais significativa nesse grupo devido à falta de técnicas de manejo adequadas e baixo uso de Equipamentos de Proteção Individual (EPI), entre outros.

A exposição aos efeitos nocivos dos agrotóxicos acomete toda população rural, incluindo idosos, jovens e crianças:

\footnotetext{
$\mathrm{Na}$ área rural, não só os produtores estão expostos aos agrotóxicos, mas também na população infanto-juvenil. É muito comum nestas áreas as crianças e principalmente os adolescentes ajudarem seus pais nas tarefas laborais. Portanto, a exposição desta parcela da população aos agrotóxicos pode representar um risco de contaminação e, consequentemente, de comprometimento do desenvolvimento físico, emocional e cognitivo de crianças e adolescentes e do processo de aprendizagem na escola e trabalho. (MOURA, 2005, p.9).
}

Portanto, torna-se evidente a necessidade da concepção de medidas legais que possibilitem a proteção ao trabalhador, que caminhem sentido a um marco regulatório internacional, bem como ações de prevenção e controle de riscos do uso destes produtos (FARIA, 2007).

\section{AGRICULTURA FAMILIAR, CAFEICULTURA E AGROTÓXICOS NO MUNICÍPIO DE GUARANÉSIA-MG}

A área de estudo retratada é o município de Guaranésia- MG estando inserida na Região Geográfica Imediata de Guaxupé no sul de Minas Gerais. Segundo dados do Censo Agropecuário de $2017,76,9 \%$ do total dos estabelecimentos agropecuários brasileiros pertencem a grupos familiares. E de acordo com a Pesquisa Agrícola Municipal (PAM/2018) o produto das lavouras temporárias e permanentes somam cerca de 5.836 hectares.

Com relação às características agrícolas do município de acordo com o Censo Agropecuário (2017) o café, a cana de açúcar, o milho e a soja são os plantios de mais destaque no município. Sendo 293 estabelecimentos agropecuários contendo o plantio de café, 23 com o plantio de cana de açúcar, 86 com o plantio de milho e 7 com o plantio de soja (IBGE, 2017).

Do somatório total da população de Guaranésia 1.876 pessoas viviam no campo sendo cerca de 250 consideradas nos atributos da lei № 11.326/2006. Através de análises dos dados obtidos junto a Empresa de Assistência Técnica e Extensão Rural do Estado de Minas Gerais (EMATER-MG), dos 250 agricultores familiares do município apenas 10 agricultores cultivam suas produções sem o uso de agrotóxicos, ou seja, 96\% dos agricultores familiares do município em questão utilizam agrotóxicos comprados principalmente na COOXUPÉ (maior cooperativa de café do mundo localizada no município de Guaxupé-MG) e em lojas de implementos e insumos agrícolas. 
Ao passo que analisamos os dados disponíveis para o município observamos uma transformação na agricultura familiar em que esta diminui a produção de alimentos e passa por um processo de "commoditização", dedicando-se à produção de commodities.

Tabela 3: Número de estabelecimentos agropecuários e produção agrícola em Guaranésia, 2006 e 2017.

\begin{tabular}{lcc}
\hline \multicolumn{1}{c}{ Cultura agrícola } & $\begin{array}{c}\text { Número de estabelecimentos } \\
\text { agropecuários, 2006 }\end{array}$ & $\begin{array}{c}\text { Número de estabelecimentos } \\
\text { agropecuários, 2017 }\end{array}$ \\
\hline Café & 230 & 293 \\
Cana de Açúcar & 17 & 23 \\
Milho & 83 & 87 \\
Soja & 0 & 7 \\
Frutas variadas & 7 & 6 \\
Feijão & 25 & $\mathbf{4 2 6}$ \\
Total & $\mathbf{3 6 2}$ & \\
\hline
\end{tabular}

Fonte: IBGE/Censo Agropecuário 2017.

Se formos analisarmos a quantidade total de estabelecimentos agropecuários presentes no município e inter-relacionarmos com a quantidade de estabelecimentos dedicados com a produção de commodities, podemos ver claramente que ocorre uma especialização de grandes monoculturas de café, cana de açúcar, soja e milho, no município, em 2006 existiam 330 propriedades rurais que se destinavam a produção de commodities, em 2017 o número chegou a 410 propriedades, um aumento de $24 \%$, ao passo que, vão desaparecendo a quantidade de lavouras dedicadas a produção de alimentos como feijão, frutas, mandioca, dentre outros.

E é nessa dinâmica que se destaca a intensa participação das cooperativas no espaço sul mineiro. Na região encontra-se a Cooxupé que é a maior e mais poderosa cooperativa de café do mundo. Atualmente, a cooperativa "possui mais de 14 mil cooperados - 95\% deles pequenos produtores que vivem da agricultura familiar," a cooperativa recebe grãos de 200 municípios no sul de Minas, Cerrado Mineiro e Vale do Rio Pardo (no estado de São Paulo) (COOXUPÉ, 2019).

A presença da produção de café é marcante na economia da região, sendo o principal produto do agronegócio e da mundialização da agricultura.

A Região Geográfica de Guaxupé, foi se tornando uma das principais regiões produtoras no Brasil e o crescimento da produção é gradativa e em 30 anos aumentou quase $600 \%$ a quantidade produzida na região. 
Tabela 4: Quantidade produzida de café em toneladas na Região Geográfica imediata de Guaxupé nos anos de 1986, 1996, 2006 e 2016.

\begin{tabular}{ccccc}
\hline Município & 1986 & 1996 & 2006 & 2016 \\
\hline Arceburgo & 550 & 2786 & 2160 & 2205 \\
Cabo Verde & 4195 & 9041 & 1740 & 12458 \\
Guaranésia & 1118 & 5710 & 5966 & 8363 \\
Guaxupé & 1502 & 7019 & 8928 & 9072 \\
Juruaia & 440 & 2562 & 5161 & 9180 \\
Monte Belo & 1888 & 6426 & 4320 & 7031 \\
Muzambinho & 2622 & 7504 & 8580 & 12177 \\
Nova Resende & 2098 & 9352 & 16128 & 20800 \\
São Pedro da União & 533 & 3195 & 5148 & 6624 \\
Total & $\mathbf{1 4 . 9 4 6}$ & $\mathbf{5 3 . 5 9 5}$ & $\mathbf{7 4 . 0 3 1}$ & $\mathbf{8 7 . 9 1 0}$ \\
\hline Fonte: CENSOS AGROPECUÁRIOS (IBGE, 1985, 1995/96, 2006, 2017).
\end{tabular}

Conforme visto na tabela acima, observa-se que Guaranésia aumentou em 7,5 vezes a quantidade produzida de café em 30 anos, acima da média regional. Esse aumento foi conseguido com incentivos estatais e sobretudo, pela atuação da COOXUPÉ, envolvendo pequenos, médios e grandes produtores do município.

A Região Geográfica Imediata de Guaxupé é caracterizada pela presença significativa da agricultura familiar, dos 10.006 estabelecimentos rurais, 8.227 são da agricultura familiar. Essa quantidade expressiva de propriedades e produtores familiares, entretanto, não se concretiza na mesma proporção na territorialização, pois ocupam $47,4 \%$ da área destinada a agricultura, e os outros $52,6 \%$ são ocupados por médias e grandes propriedades.

O café é o produto agrícola de maior representatividade sendo do total de estabelecimentos 293 produtores de café, correspondendo a 3.180 hectares de áreas plantada o que produziu 8.363 toneladas em 2016 (Figura 2). A cana de açúcar outro produto do agronegócio local é produzido em 18 estabelecimentos ocupando uma área equivalente a 1.123 hectares que produziram 85.785 toneladas em 2018.

Quanto à territorialização do café nos municípios da Região Geográfica de Guaxupé, essa cultura agrícola ocupa 46.595 hectares, dos 83.041 hectares destinado a agropecuária, ou seja, 56\% do espaço agrário é dominado pela cafeicultura.

A ocupação territorial do café no espaço agrária, demostra como o agronegócio cafeeiro atinge todos estratos de produtores rurais. Com forte presença da agricultura familiar na região, o café está territorializado em 10.000 hectares no município de Cabo Verde, e em 3.180 hectares em Guaranésia. 


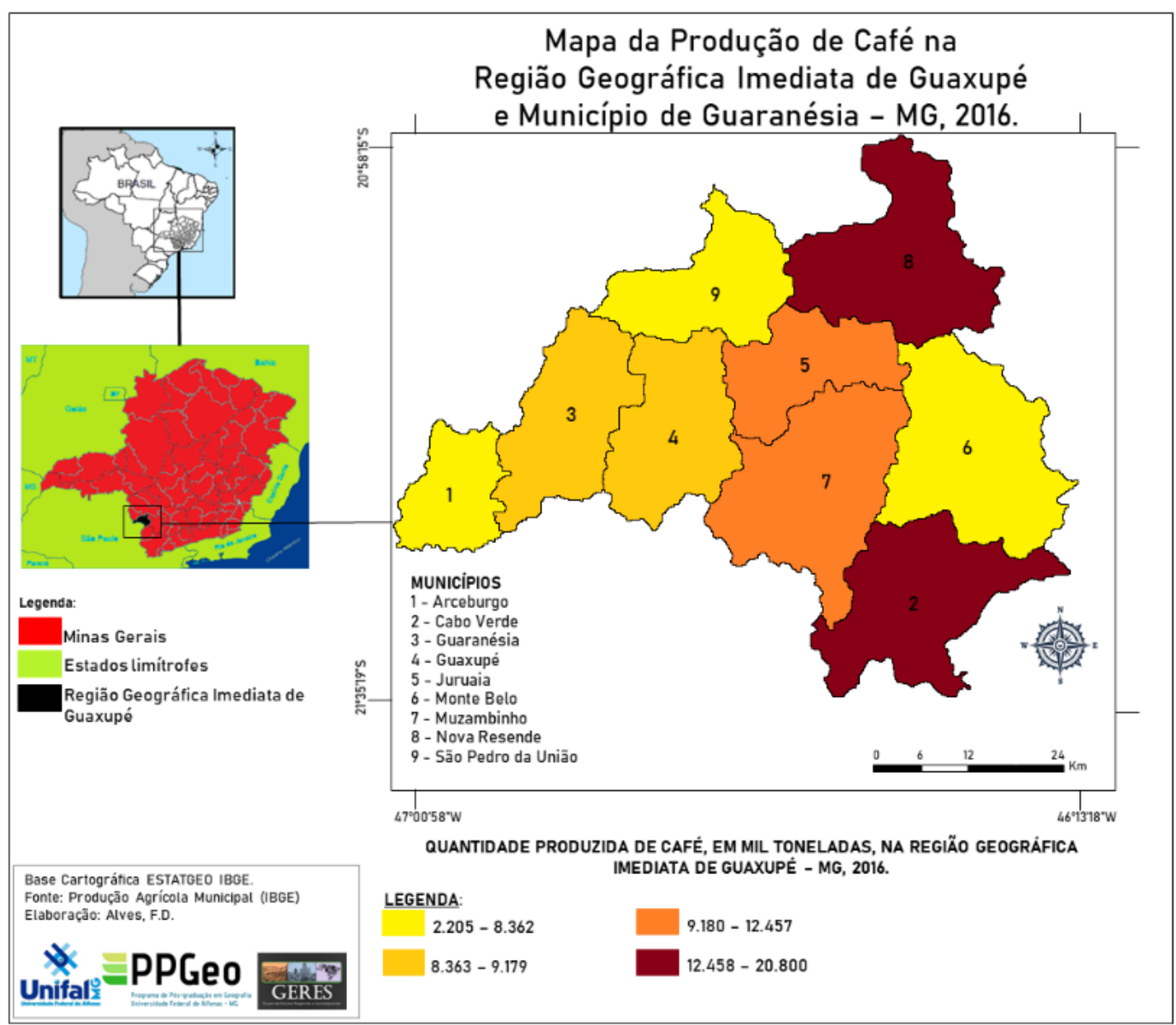

Figura 2 - Mapa da Produção de Café na Região Geográfica Imediata de Guaxupé, 2016.

Fonte: MELO; ALVES; (2020, p. 223).

Um fator preocupante em relação às características destes agricultores está na baixa escolaridade que quando atrelada ao uso de agrotóxicos podem ter consequências catastróficas a saúde dos mesmos, de acordo com os dados obtidos pelo Censo Agropecuário (2017) cerca de 69\% dos agricultores cursaram apenas o ensino fundamental. A baixa escolaridade pode ocasionar dificuldades de interpretação das orientações de manejo seguro impressas nas embalagens, como também nas dosagens utilizadas, formas de descarte de embalagens, armazenagens dentre outras medidas essenciais para a segurança do trabalhador.

A comercialização dos venenos utilizados na agricultura do município se efetua por meio da Cooxupé que trabalha como um grande atravessador intermediando as relações cafeicultor/mercado consumidor. Além disso, a cooperativa presta assistência técnica, são também distribuidoras de insumos para agricultura, abrangendo uma linha bem diversificada de produtos, que compreende de máquinas agrícolas a adubos e defensivos agrícolas.

Com relação ao uso de agrotóxicos no café aproximadamente 121 tipos são permitidos no Brasil destes, pelo menos 30 são proibidos na União Europeia, uma contradição já que a Europa ao comprar o café do Brasil recebe indiretamente o veneno ao qual tenta coibir (BOMBARDI, 2017). 
De acordo com o Censo agropecuário do IBGE de 2017 os estabelecimentos agropecuários ocupam uma área equivalente a 23.691 hectares, dos 563 estabelecimentos agropecuários sendo em sua maioria de posse de proprietários individuais, adultos, do sexo masculino e com ensino fundamental incompleto. A maioria (286 estabelecimentos) recebe assistência técnica, realiza a adubação frequente (409 estabelecimentos), obtiveram financiamento (PRONAF) para custeio de sua produção (467 estabelecimentos) e utilizam agrotóxicos (363 estabelecimentos). No contexto sul mineiro, mais de 60 mil propriedades rurais utilizaram agrotóxicos em suas plantações.

Das 15 regiões geográficas imediatas que compõem o Sul de Minas Gerais, as que mais consomem agrotóxicos na produção agrícola, são aquelas que estão ligadas ao agronegócio do café. As regiões imediatas de Pouso Alegre, Alfenas e Guaxupé lideram o consumo de agrotóxico, com 11.597, 9.972 e 7.190 estabelecimentos rurais respectivamente. Guaranésia estando na Região Geográfica Imediata de Guaxupé, confirma a relação entre agrotóxico e a cafeicultura.

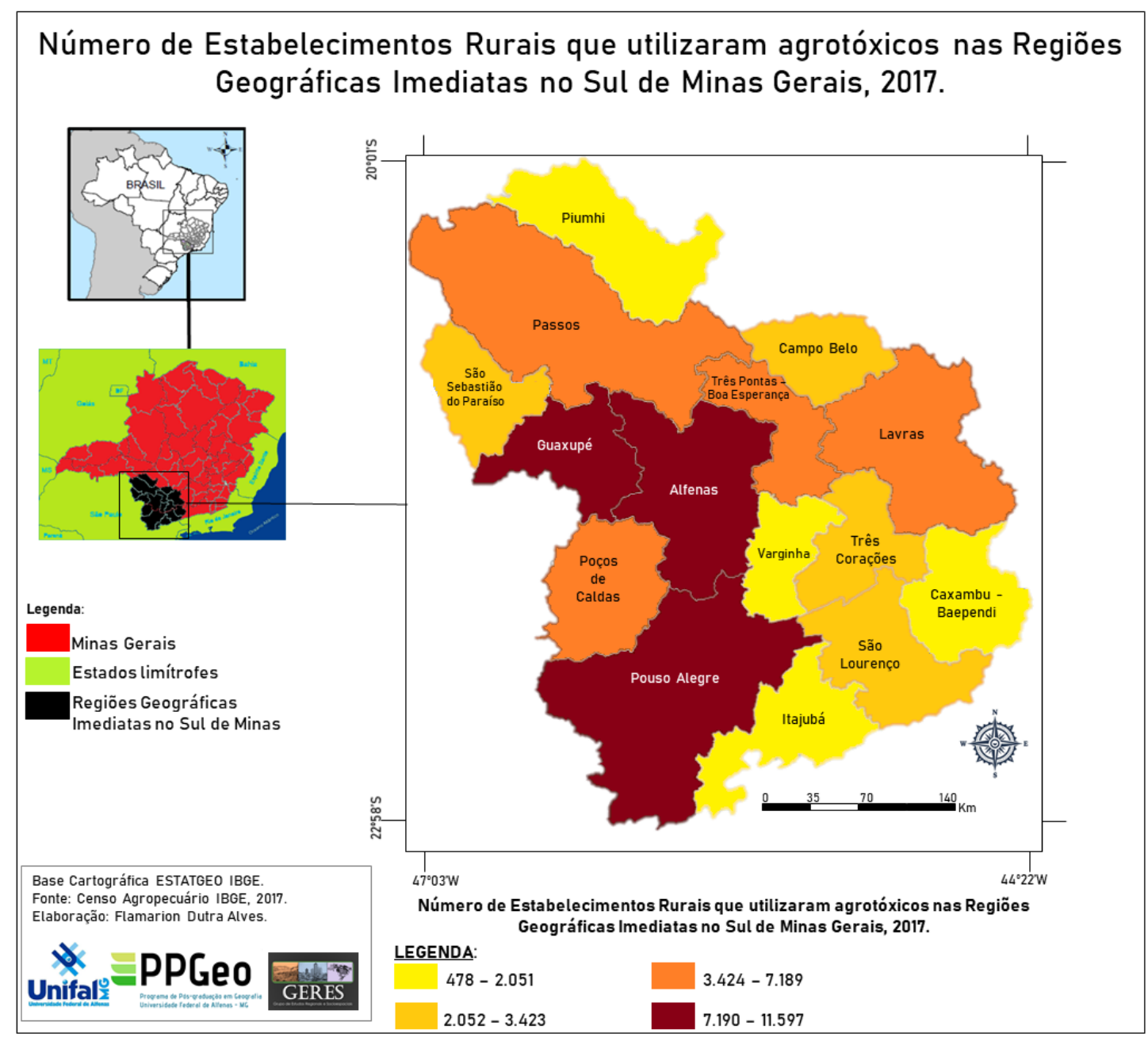

Figura 3 - Total de estabelecimentos rurais que utilizaram agrotóxico no Sul de Minas Gerais em 2017 Fonte: MELO; ALVES (2020, p.226). 
Conforme os dados do Censo Agropecuário de 2006, no sul de Minas Gerais foram notificados 285 casos de intoxicação por agrotóxico, mas 38.927 propriedades rurais fizeram uso do agrotóxico nas suas lavouras, demostrando territorialização na agricultura, tanto nas propriedades de caráter familiar como nas empresariais e multinacionais (ALVES, 2019a).

Em relação ao nosso município de estudo entre os anos de 2010 (início das notificações) até 2020 Guaranésia registrou 32 intoxicações por agrotóxicos sendo esses de uso agrícola (90\% das intoxicações) e também de uso urbano (Ministério da Saúde/DATASUS/SINAN, 2020). Diante da existência de subnotificação dos casos de intoxicação exógena no Brasil, é importante destacar que o aumento do número de notificações evidencia que os casos são de suma importância como alerta governamental para subsidiar os processos de planejamento, gestão e avaliação de políticas públicas relacionadas à vigilância em saúde ambiental, visando prevenção de riscos à saúde decorrentes de intoxicação exógenas sobretudo por agrotóxicos utilizados em lavouras.

Nas propriedades rurais os entrevistados trabalham em regime familiar, que varia de 1 até 7 integrantes da mesma família ligados as atividades laborais, destacamos que o trabalho familiar é uma característica específica requisitada pela lei 11.326/06 para considerar o produtor na modalidade da agricultura familiar. Em consonância com os dados levantados, a população do campo é composta em sua maioria por pessoas na fase adulta e também por idosos. Os números encontrados interferem diretamente na diminuição da população de residentes rurais, se por lado, o envelhecimento da população relaciona-se com a melhoria nas condições de vida que permite maior longevidade, por outro lado, constitui uma problemática da defasagem de mão de obra no campo.

Os indicadores educacionais demonstram que há grandes divergências entre o rural e o urbano, mesmo que nessa pesquisa o nível de escolaridade se apresenta de forma regular, há uma desigualdade educacional que varia em relação aos Estados, municípios e regiões brasileiras, tal discrepância se justifica pela limitação ao acesso a instituições educacionais pela população rural, e constituem entraves para superação da desigualdade social e consequentemente da pobreza no campo.

Em menor proporção temos no município de estudo cultivos das olerícolas, frutas e leite, esses produtos alimentícios setorizados na categoria de olericulturas que abrange a exploração de hortaliças englobam culturas folhosas, raízes, bulbos, tubérculos, frutos diversos, partes comestíveis de plantas e frutas. Em sequência podemos visualizar uma foto da produção de hortaliças em uma propriedade visitada.

Além da produção de hortaliças, a propriedade tem investido na produção de peixes em regime de aquaponia.

Os canais de comercialização registrados nesta pesquisa possuem uma relevância significativa, pois representam a última etapa do processo produtivo sendo influenciadores diretos na continuidade das atividades de produção no campo ressalta a comercialização direta e sobrepujante 
com a Cooperativa Regional doa Agricultores de Guaxupé-MG (Cooxupé) em sequência com a rede de supermercados, escolas e feiras sendo esses os locais de venda escolhidos pelos agricultores como os melhores canais de comercialização para atender as suas necessidades.

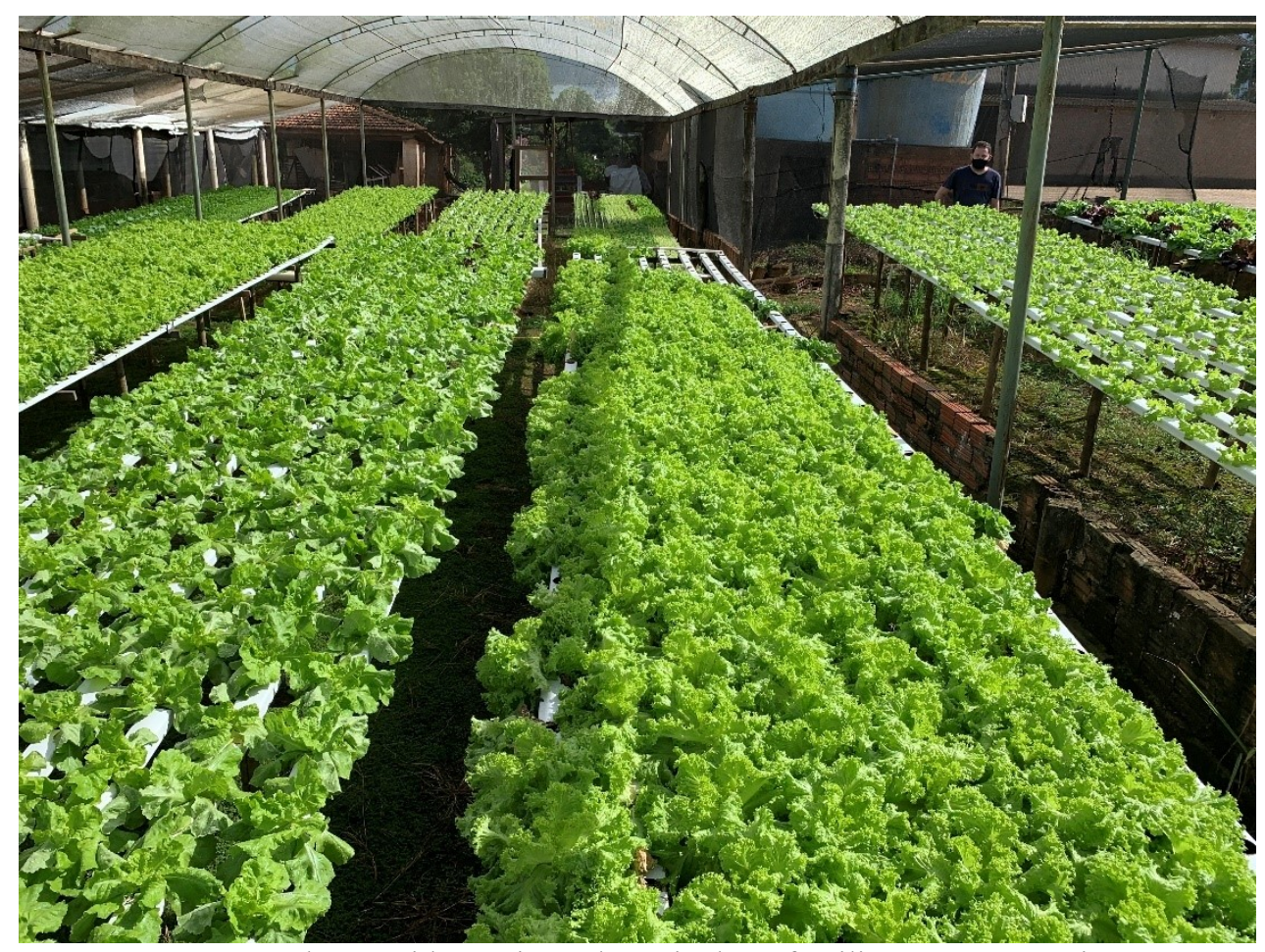

Figura 4 - Produção Hidropônica pela agricultura familiar em Guaranésia-MG.

Fonte: Trabalho de campo, 2021.

No intuito de esclarecer questões relacionadas com o uso de agrotóxicos nos cultivos evidenciou-se que $90 \%$ dos produtores fazem uso de tais substâncias no manejo de suas produções.

Do montante dos produtores que utilizam agrotóxicos em seus cultivos, 60\% relatam a ocorrência de tipos de cânceres em familiares que atuam ou atuaram nessas propriedades. Tais agricultores demonstram receio na utilização dessas substâncias, embora reconheçam a praticidade na compra e utilização desses produtos que exercem a função auxiliar do processo produtivo.

Outro importante fator abordado foi o uso de Equipamento de Proteção Individual (EPI) no manejo agrícola. No setor agrícola, o EPI rural é uma ferramenta de trabalho e o seu uso é muito importante para preservar a saúde do trabalhador do campo evitando possíveis intoxicações. Devido a isso, ele se tornou obrigatório por lei.

Durante a pesquisa de campo os entrevistados asseguraram o uso de proteção como: botas, máscaras, luvas, macacão, óculos de proteção, boné, chapéu e calça.

Todavia o local para armazenamento de EPIs e vasilhames é inapropriado mesmo tendo $80 \%$ dos produtores rurais afirmado que conhecem as regras de armazenamento, limpeza, manutenção e descarte de EPIs e embalagens de agrotóxicos. 
Dentre os sintomas relatados por $20 \%$ dos entrevistados que sofreram com incidentes causados pelo uso de agrotóxicos no dia a dia estão: dores de cabeça, dificuldade respiratória, diarreia, náuseas, manchas ou irritações diferentes na pele, fraqueza, entretanto os mesmos afirmaram que não buscaram serviços hospitalares como hospitais, pronto socorro, unidades de pronto atendimento e postos de saúde, fator que acarreta em subnotificações dos casos de intoxicação química advindo de produtos agropecuários.

Como mencionado anteriormente o Brasil está na liderança do consumo de agrotóxicos no mundo todo, nesta conjuntura pressupõe-se altas despesas de capital para aquisição dos mesmos o que compromete a renda dos agricultores e consequentemente a lucratividade de suas produções.

$\mathrm{Na}$ agricultura familiar não é diferente, os gastos registrados em nossa pesquisa chegam a atingir a casa dos 100 mil reais anuais em lavouras maiores de café. O que faz com que muitos agricultores dependam da disponibilidade de crédito agrícolas para comprar desses e outros insumos.

Em uma perspectiva econômica abrangendo os gastos com mão de obra, implementos agrícolas, agrotóxicos, sementes, $50 \%$ dos consultados alegaram que suas propriedades não geram nem lucros nem prejuízos devido ao grande dispêndio de capital para a plantação, manutenção e beneficiamento de seus produtos inter-relacionados a volatilidade dos preços de mercado. Esse quadro implica na necessidade de políticas públicas direcionadas ao aumento da renda desse setor para garantir a permanência e estimulo dessa população nas atividades rurais.

\section{CONSIDERAÇÕES FINAIS}

A entrada do Brasil no mercado globalizado tem forte influência nas ações desenvolvidas pelo Estado Brasileiro que viabilizaram o caminho do desenvolvimento da agricultura capitalista a fim de inserir o país no mercado mundial de comercialização de produtos agrícolas.

Tais aspectos culminaram na liderança no ranking de consumo de agrotóxicos no mundo, sendo essa realidade o reflexo das condições históricas que incentivaram a utilização de agrotóxicos nas práticas agrícolas ligadas ao agronegócio e até mesmo a agricultura familiar.

Observamos que agricultura familiar é composta por grupos heterogêneos afirmamos que o meio rural se caracteriza por sua imensa diversidade de classes de agricultores familiares com anseios e demandas diferenciadas.

No tocante a legislação brasileira, foi possível visualizar que a mesma apresenta ambiguidades, distorções e fragilidades, percebeu-se também, uma transformação do espaço rural em um espaço dedicado a produzir commodities ao mercado global.

O local de estudo, Guaranésia situada no sul de Minas Gerais, está inserida nesse processo de territorialização e monopolização do capital na agricultura. A cafeicultura incorpora os agricultores 
familiares nesse processo de mundialização da agricultura, e a presença marcante da Cooxupé corrobora a perpetuação dessa realidade, onde o agricultor familiar que não se encaixa nos padrões de produção capitalista de commodities acaba ocupando uma posição marginalizada nesse contexto, onde políticas públicas e mercado consumidor consolidado estão mais direcionados ao café.

A dependência econômica dos agricultores familiares com a cafeicultura ficou evidente, sendo uma relação amarrada aos interesses do mercado internacional e viabilizada pela cooperativa e redes bancárias de crédito rural. Nesse panorama o agricultor tem poucas chances de produzir sem atrelar a sua produção e seu lucro a instituições financiadoras, no entanto, como salientado a resistência econômica do agricultor familiar as externalidades negativas do processo capitalista de produção faz com que na grande maioria das vezes suas propriedades não atinjam a lucratividade desejada ou pior acumulem déficits, gerando prejuízos.

Entretanto, encontramos espaços de resistência ao domínio do capital no campo formados por agricultores familiares que atendem as demandas alimentícias da população através do cultivo de produtos de origem orgânica com boas práticas no manejo para a preservação dos recursos naturais e produção de produtos saudáveis livres de agrotóxicos.

Sendo assim, é urgente repensar os modos de produção, evitando que a produção agrícola agrida o meio ambiente e a saúde humana para que todos possam ter acesso a alimentos nutritivos que não contenham cargas de veneno, intoxicações e mortes de trabalhadores nos processos de produção e nem ocasionem consequências as futuras gerações.

É de importância fundamental para a vida humana o resgate ao equilíbrio ecológico, a dignidade social e cultural, para isso é inconcebível a permanência dos modos convencionais de produção.

\section{REFERÊNCIAS}

ABRAMOVAY, R.; PIKETTY, M. G. Política de crédito do Programa Nacional de Fortalecimento da Agricultura Familiar (PRONAF): resultados e limites da experiência brasileira nos anos 90 . Cadernos de Ciência \& Tecnologia, v. 22, n. 1, p. 53-66, 2005.

ABRAMOVAY, R. Uma nova extensão rural para a agricultura familiar. In: SEMINÁRIO NACIONAL DE ASSISTÊNCIA TÉCNICAE EXTENSÃO RURAL, Brasília. Anais... Brasília: PNUD, 1997.

ALTIERI, M. A. El "estado del arte" de la agroecología y su contribución al desarrollo rural en América Latina. In: CADENAS MARÍN, A. (Ed.). Agricultura y desarrollo sostenible. Madrid: MAPA, 1995. p. 151-203.

BOMBARDI, L. M. Geografia do Uso de Agrotóxicos no Brasil e Conexões com a União Europeia. São Paulo: FFLCH - USP, 2017. 296p. 
BRASIL. Lei n. 11.326/2006 de 24 de julho de 2006. Brasil, Brasília, 24 jul. 2006. Disponível em: http://www.planalto.gov.br/ccivil_03/_ato2004-2006/2006/lei/111326. Acesso em: 26 out. 2020.

CAPORAL, F. R.; COSTABEBER, J. A. Agroecologia: alguns conceitos e princípios. Brasília: Embrapa, 2004. 24p.

CHESNAIS, F. La mondialisation du capital. Tradução: Ruy Braga. Syros, 1997. 286p.

FARIAS, N. M. X.; FASSA, A. G.; FACCHINI, L. A. Intoxicação por agrotóxicos no Brasil: os sistemas oficiais de informação e desafios para realização de estudos epidemiológicos. Ciência e saúde coletiva, v. 12, n. 1, p. 25-38, 2007.

FERREIRA, M. L. P. C. A pulverização aérea de agrotóxicos no Brasil: cenário atual e desafios. Revista de Direito Sanitário, São Paulo, v. 15, n. 3, p. 18-45, 2014.

GARCIA E. G.; BUSSACOSA, M. A.; FISCHERB, F. M. Impacto da legislação no registro de agrotóxicos de maior toxicidade no Brasil. Revista de Saúde pública, v. 39, n. 5, p. 832-839, 2005.

GARCIA, E. G.; ALVES FILHO, J. P. Aspectos de prevenção e controle de acidentes no trabalho com agrotóxicos. São Paulo: Fundacentro, 2005. 51p.

GRAZIANO DA SILVA, J. A nova dinâmica da agricultura brasileira. Campinas: UNICAMP, 1996. 228p.

LEFF, E. - Agroecologia e saber ambiental. Agroecologia e Desenvolvimento Rural Sustentável. Porto Alegre, v. 3, n. 1, p. 36-51, 2002.

LOBATO, S. M. R. O silêncio como metáfora: o uso de agrotóxicos e a saúde dos trabalhadores no município de Iguapé-Açu - PA. 2003. 248 f. Tese (Doutorado em Ciências Socioambientais) Universidade Federal do Pará, Belém, 2003.

MELO, R. V.; ALVES, F. D. - Mundialização da agricultura e o uso de agrotóxicos no município de Guaranésia - MG. Campo-Território: revista de geografia agrária, v. 15, n. 36, p. 199-229, 2020.

OLIVEIRA, A. U. A mundialização do capital e a crise do neoliberalismo: o lugar mundial da agricultura brasileira. Geousp - Espaço e Tempo, v. 19, n. 2, p. 229-245, 2015.

OLIVEIRA, A. U. A mundialização da agricultura brasileira. In: COLOQUIO INTERNACIONAL DE GEOCRÍTICA., 12. 2012, Bogotá. Anais... Bogotá: Universidad Nacional de Colombia, 2012.

OLIVEIRA, A. U. Modo de produção capitalista, agricultura e reforma agrária. São Paulo: FFLCH, 2007. 88p.

PERES, F.; ROZEMBERG, B.; ALVES, S. R.; MOREIRA, J. C.; OLIVEIRA-SILVA, J. J. Comunicação relacionada ao uso de agrotóxicos em uma região agrícola do Estado do Rio de Janeiro. Revista de Saúde Pública, v. 35, n. 6, p. 564-570, 2001.

PERES, F. É veneno ou é remédio? os desafios da comunicação rural sobre agrotóxicos. 1999. 372 f. Dissertação (Mestrado em Saúde Pública) - Escola Nacional de Saúde Pública, Rio de Janeiro, 1999. 
PICOLOTTO, E. L. - Os Atores da Construção da Categoria Agricultura Familiar no Brasil. RESR., Piracicaba, v. 52, n. 1, p. 63-84, 2014.

PLOEG, J. D. V. D. Camponeses e impérios alimentares: lutas por autonomia e sustentabilidade na era da globalização. Porto Alegre: Editora da UFRGS, 2008. 376p.

RAFESTIN, C. Por uma Geografa do Poder. São Paulo: Ática, 1993. 266p.

PORTO, M.; SOARES, W. Modelo de desenvolvimento, agrotóxicos e saúde: um panorama da realidade agrícola brasileira e propostas para uma agenda de pesquisa inovadora. Revista Brasileira de Saúde Ocupacional, São Paulo, v. 37, n. 125, p. 46-49, 2012.

SAMPAIO, R. M. O; GONÇALVES NETO, J. C. O paradigma da intensa utilização de agrotóxicos no brasil sob o contexto da mundialização da agricultura. Rev. de Direito Agrário e Agroambiental, Salvador, v. 4, n. 1, p. 111-129, 2018.

SCHNEIDER, S. Situando o desenvolvimento rural no Brasil: o contexto e as questões em debate. Revista de Economia Política, v. 30, n. 3, p. 511-531, 2010.

VEIGA, J. E. V. Problemas da transição à agricultura sustentável. Estudos Econômicos, São Paulo,v. 24, p. 9-29, 1994. 